\title{
Effect of Supplementation of Non Starch Polysaccharide Hydrolyzing Enzymes on Performance of Broilers
}

\author{
M. G. Nikam ${ }^{1}$, V. Ravinder Reddy ${ }^{2}$ \\ Department of Poultry Science, College of Veterinary Science, Rajendra nagar, Hyderabad, India
}

\begin{abstract}
Two hundred and fifty one-day old Ven-Cobb straight run commercial broiler chicks were supplemented with the NSP hydrolyzing enzymes at $1 X(H C)$ concentrations viz. (xylanase, $\beta$-D-glucanase, cellulase, mannanase and pectinase @ 2400, 4800, 1800, 4800, and $2400 \mathrm{IU} / \mathrm{kg}$ respectively. The similar enzyme combination was supplemented @ 4800,9600,3600,9600 and 4800 IU/kg respectively as $2 X(H C)$ to the corn + soybean meal based standard diet. Similarly the corn + soybean meal diet was supplemented with NSP hydrolyzing enzymes at $1 X(L C)$ viz. (xylanase, $\beta$-D-glucanase, cellulase, mannanase and pectinase @ 400, 240, 200, 200, and 400 IU/kg respectively. The same NSP hydrolyzing enzyme combination was supplemented @ 800,480,400,400 and 800 IU/Kg respectively as $2 X(L C)$. The birds were weighed, wing banded and randomly distributed in to five experimental groups, with ten replicates and five birds in each replicate to assess the effect of the NSPHE combination on growth performance of broilers. Significant (P<0.05) differences were observed with the weekly body weight gain, feed intake, and feed conversion ratio when the birds were supplemented with NSP hydrolyzing enzymes at $1 X(H C)$. However the NSP hydrolyzing enzymes did not influenced the overall performance of broilers when supplemented @ $2 X(H C), 1 X(L C)$ and $2 X(L C)$ to the corn soybean meal based diets.
\end{abstract}

Keywords: Non starch polysaccharide hydrolyzing enzymes, lower concentration, higher concentration

\section{Introduction}

Cereals and vegetable protein sources form the major ingredients in poultry rations. These ingredients contain between $10-75 \%$ of non-starch polysaccharides (NSP) (Chot, 2011). The NSP in cereals form a part of the cell wall structure and in vegetable proteins, especially legumes, play a role as an energy storage material. Chicken having a simple stomach, cannot digest complex nutrients like nonstarch polysaccharides (NSP) and phytate. Supplementation of chicken diet with fiber degrading enzymes and phytase is known to enhance utilization of the complex carbohydrate moiety and phytate phosphorus (Choct, 2006). With the continuous increase in world's population and the decline in its food reserve, a more efficient conversion of by-products, including those rich in NSP, into high quality food is a top priority area of research today.

The commercial application of feed enzymes has a history of less than 20 years. During this period, the feed enzyme industry came into existence and it has gone through several phases of development. The first phase was the use of enzyme to enhance nutrient digestibility, focusing primarily on minimizing the anti-nutritive effect of NSP, such as arabinoxylans and $\beta$-glucans from broiler diets based on wheat, rye, barley or triticale which increase the viscosity of digesta. During the early 1990s the scope of enzyme application expanded to other nutrients like phytase besides NSP (Choct, 2006).

In recent years, soybean meal (SBM) is being used as sole protein source which contains about 20\% NSP (Malathi and Devegowda, 2001). Similarly, other major ingredients used in broiler and layer diets i.e., maize and rice bran contains 9 and 25\% NSP, respectively (Malathi and Devagowda, 2001) half of which is cellulose (Saunders, 1986). The NSPs are insoluble (cellulose) and soluble ( $\beta$-glucose, arabinoxylan, arabinogalactose, xyloglucon etc). The soluble NSPs have the property to immobilize water in its matrix by forming loose gel network which is responsible for increased viscosity, there by depressing the digestibility of fats, proteins and starch. These NSPs impair activity of endogenous enzymes by reducing the contact intensity between nutrients and enzymes, which results in sticky and moist droppings.

Use of feed enzymes to improve the nutritive value of poultry diets has become common practice in many countries due to use of feed ingredients containing higher proportion of NSP. Hong et al. (2002) found that the use of an enzyme cocktail (Xylanase, amylase and protease) improved the digestibility of corn-soybean based diets in ducks. Using enzymes in poultry diets not only enhance bird performance and feed conversion, but also reduce environmental problems due to reduced concentration of nutrients in excreta. Similarly the other possible benefits are increased accuracy and flexibility in least-cost feed formulation and improved well being of the birds.

\section{Materials and Methods}

The experiment was conducted on two hundred and fifty (250) one day old straight run Ven-Cobb commercial broiler chicks supplemented with the NSP hydrolyzing enzymes viz xylanase, B-d-glucanase, cellulase, mannase and pectinase at higher (HC) as well as lowers concentrations (LC) on cornsoybean meal diet (Table 1) with iso caloric and iso nitrogenous levels. These pure enzymes were procured from Advanced Bio- Agrotech Limited, Pune, India. The activity of xylanase, $\beta$-d-glucanase, cellulase, mannase and pectinase was $160000,200000,1000000,200000 \mathrm{IU} / \mathrm{g}$, and 150000 respectively. The birds were weighed, wing banded and randomly distributed in to five experimental groups, with ten replicates and five birds in each replicate (Table 2). All the 


\section{International Journal of Science and Research (IJSR) \\ ISSN (Online): 2319-7064 \\ Index Copernicus Value (2013): 6.14 | Impact Factor (2014): 5.611}

birds were reared under standard managemental conditions. The details of the NSPHE and ingredient composition for the experiment I have been given in (Table 3). The data were subjected to appropriate statistical analysis using Statistical Package for Social Sciences (SPSS) $15^{\text {th }}$ version and comparison of means was tested using Duncan's multiple range tests (Duncan's, 1955).
Table 1: Details of experimental diets broiler experiment

\begin{tabular}{|c|c|c|c|c|}
\hline \multirow[t]{2}{*}{ Diet } & \multirow[t]{2}{*}{ Dietary group } & \multicolumn{3}{|c|}{$\begin{array}{l}\text { Metabolizable energy } \\
\text { (kcal/kg diet) }\end{array}$} \\
\hline & & Pre-starter & Starter & Finisher \\
\hline I & $\begin{array}{c}\text { Control corn - soybean meal } \\
\text { Diet without NSPHE }\end{array}$ & 2950 & 3050 & 3150 \\
\hline II & Control + 1X (HC) NSPHE & 2950 & 3050 & 3150 \\
\hline III & Control + 2X (HC) NSPHE & 2950 & 3050 & 3150 \\
\hline IV & Control + 1X (LC) NSPHE & 2950 & 3050 & 3150 \\
\hline V & Control + 2X (LC) NSPHE & 2950 & 3050 & 3150 \\
\hline
\end{tabular}

Table 2: Details of the NSP hydrolyzing enzyme concentrations selected for broiler experiment

\begin{tabular}{|c|c|c|c|c|c|}
\hline \multicolumn{6}{|c|}{ Higher Combinations (HC) - for diets with corn - soybean meal } \\
\hline $\begin{array}{c}\text { Percentage of } \\
\text { Enzyme }\end{array}$ & Xylanase (IU/kg) & $\begin{array}{c}\beta-D-g l u c a n a s e \\
(\mathrm{IU} / \mathrm{kg})\end{array}$ & $\begin{array}{c}\text { Cellulase } \\
(\mathrm{IU} / \mathrm{kg})\end{array}$ & Mannanase (IU/kg) & Pectinase (IU/kg) \\
\hline $60 \%(1 \mathrm{X})$ & 2400 & 4800 & 1800 & 4800 & 2400 \\
\hline $120 \%(2 \mathrm{X})$ & 4800 & 9600 & 3600 & 9600 & 4800 \\
\hline \multicolumn{7}{|c|}{ Lower combinations (LC) - for diets with corn soybean meal } \\
\hline $200 \%(\mathbf{1 X})$ & 400 & 240 & 200 & 200 & 400 \\
\hline $400 \%(\mathbf{2 X})$ & 800 & 480 & 400 & 400 & 800 \\
\hline
\end{tabular}

Table 3: Ingredient composition of experimental diets of broiler Experiment

\begin{tabular}{|l|l|l|l|}
\hline \multicolumn{1}{|c|}{ Ingredient (g/kg) } & Prestarter & \multicolumn{1}{c|}{ Starter } & Finisher \\
\hline Maize & 524.48 & 571.04 & 623.04 \\
\hline Soybean meal & 402.32 & 372.05 & 310.51 \\
\hline Oil (veg) & 31.32 & 17.24 & 28.96 \\
\hline Salt & 3.8 & 3.8 & 3.8 \\
\hline DL-Methionine & 2.040 & 2.21 & 1.89 \\
\hline Di-Calcium Phosphate & 19.97 & 17.24 & 16.17 \\
\hline Shell grit & 10.60 & 11.45 & 10.89 \\
\hline Trace mineral mixture & 1.00 & 1.00 & 1.00 \\
\hline AB2D3K ${ }^{2}$ & 0.150 & 0.150 & 0.150 \\
\hline B-Complex & 0.100 & 0.100 & 0.100 \\
\hline Choline Chloride, 50\% & 0.50 & 0.50 & 0.50 \\
\hline Toxin Binder & 2.0 & 2.0 & 2.0 \\
\hline Antibiotic & 0.50 & 0.50 & 0.50 \\
\hline L-lysine HCL & 0.720 & 0.410 & 0.00 \\
\hline Coccidiostat & 0.50 & 0.50 & 0.50 \\
\hline Tylan & 0.50 & 0.50 & 0.50 \\
\hline Total & $\mathbf{1 0 0 0}$ & $\mathbf{1 0 0 0}$ & $\mathbf{1 0 0 0}$ \\
\hline Nutrient Composition (calculated) & \multicolumn{2}{|l}{} \\
\hline ME(kcal/kg) & 2950.00 & 3050.00 & 3150.00 \\
\hline Protein (\%) & 23.00 & 21.00 & 19.50 \\
\hline Calcium (\%) & 0.90 & 0.85 & 0.80 \\
\hline Available phosphorus (\%) & 0.45 & 0.40 & 0.38 \\
\hline Lysine (\%) & 1.36 & 1.20 & 1.07 \\
\hline Methionine (\%) & 0.56 & 0.55 & 0.50 \\
\hline & \multicolumn{5}{l}{} \\
\hline
\end{tabular}

1 Trace mineral provided per $\mathrm{kg}$ diet: manganese, $120 \mathrm{mg}$; Zinc, $80 \mathrm{mg}$; Iron, 25mg; Copper, 10mg; Iodine, $1 \mathrm{mg}$; and Selenium, $0.1 \mathrm{mg}$. ${ }^{2}$ Vitamin premix provided per $\mathrm{kg}$ diet: Vitamin A, 20000IU; Vitamin $\mathrm{D}_{3}$, 3000IU; Vitamin E, 10mg; Vitamin K,2mg; ${ }^{3}$ Riboflavin, 25mg; Vitamin $B_{1}$, $1 \mathrm{mg}$; Vitamin $\mathrm{B}_{6}, 2 \mathrm{mg}$ : vitamin $\mathrm{B}_{12}, 40 \mathrm{mcg}$ and Niacin, $15 \mathrm{mg}$

\section{Results}

The performance of commercial straight run broiler chicks fed on various levels of NSPHE to the diet containing corn soybean meal based standard diet was studied in terms of body weight gain, feed intake and feed conversion ratio. Highest BWG was observed in birds fed with corn -soy diet with 1X (HC) NSPHE throughout the experimental period at. The NSPHE did not shown any significant effect on BWG when fed @2X (HC), 1X and 2X (LC).However the diets supplemented with NSPHE@2X (HC) showed poor body weight gain during the pre starter and finisher phase except for the starter phase, where it has shown some encouraging results with weekly as well as phase wise body weight gain (Table 4). The diets supplemented with NSPHE (a) $1 \mathrm{X}$ and $2 \mathrm{X}(\mathrm{LC})$ showed significantly $(\mathrm{P}<0.05)$ higher feed intake during pre-starter phase .However the diets supplemented with NSPHE @1X (HC) have shown significantly $(\mathrm{P}<0.05)$ higher feed intake during starter and finisher phase compared to birds fed with NSPHE @ 2X (HC), 1X and 2X (LC) (Table 5). The phase wise feed conversion ratio was significantly better $(\mathrm{P}<0.05)$ in birds fed with NSPHE@1X (HC) when compared to rest of the treatment groups during pre-starter phase. During the starter phase, birds receiving the NSPHE @ 2X (HC) showed significantly better FCR compared to other treatment groups. The Finisher phase showed significantly higher FCR in the control group followed by NSPHE supplemented @ 1X (HC) and 2X (LC) respectively. The diets with NSPHE@ 2X (HC) and 1X (LC) showed poor FCR during finisher phase (Table 6).

Table 4: Effect of supplementation of non starch Polysaccharide hydrolyzing enzymes to corn soybean meal diets on phase wise body weight gain $(\mathrm{g})$ of broilers (1-6 wks of age).

\begin{tabular}{|c|c|c|c|c|c|}
\hline Treatments & Enzymes & $\begin{array}{c}\text { Prestarter } \\
0-14 d\end{array}$ & $\begin{array}{c}\text { Starter } \\
15-28 d\end{array}$ & $\begin{array}{c}\text { Finisher } \\
29-42 d\end{array}$ & $\begin{array}{c}\text { Total } \\
0-42 d\end{array}$ \\
\hline $\mathrm{T}_{1}$ & 0 & $324.4^{\mathrm{ab}}$ & $854.1^{\mathrm{ab}}$ & $1,194.0^{\mathrm{ab}}$ & $2,372.4^{\mathrm{ab}}$ \\
\hline $\mathrm{T}_{2}$ & $1 \mathrm{X} \mathrm{HC}$ & $334.8^{\mathrm{a}}$ & $886.0^{\mathrm{a}}$ & $1,225.8^{\mathrm{a}}$ & $2,446.6^{\mathrm{a}}$ \\
\hline $\mathrm{T}_{3}$ & $2 \mathrm{X} \mathrm{HC}$ & $314.4^{\mathrm{b}}$ & $867.9^{\mathrm{ab}}$ & $1,013.1^{\mathrm{c}}$ & $2195.4^{\mathrm{c}}$ \\
\hline $\mathrm{T}_{4}$ & $1 \mathrm{X} \mathrm{LC}$ & $315.1^{\mathrm{b}}$ & $795.9^{\mathrm{bc}}$ & $1,135.0^{\mathrm{b}}$ & $2,246.0^{\mathrm{bc}}$ \\
\hline $\mathrm{T}_{5}$ & $2 \mathrm{X} \mathrm{LC}$ & $295.9^{\mathrm{c}}$ & $818.3^{\mathrm{c}}$ & $1,089.4^{\mathrm{c}}$ & $2,203.6^{\mathrm{c}}$ \\
\hline \multicolumn{2}{|c|}{ SEM } & 2.72 & 8.87 & 14.22 & 19.58 \\
\hline \multicolumn{2}{|c|}{$\mathrm{P}$ value } & 0.002 & 0.001 & 0.037 & 0.003 \\
\hline \multicolumn{6}{|r}{} \\
\hline
\end{tabular}

\section{Volume 4 Issue 12, December 2015}




\section{International Journal of Science and Research (IJSR) \\ ISSN (Online): 2319-7064 \\ Index Copernicus Value (2013): 6.14 | Impact Factor (2014): 5.611}

Values bearing different superscripts within a column are significantly $(\mathrm{P}<0.05)$ different

Table 5: Effect of supplementation of non starch polysaccharide hydrolyzing enzymes to corn soybean diets on phase wise feed intake (g) of broilers (1-6 wks of age).

\begin{tabular}{|c|c|c|c|c|c|}
\hline Treatments & Enzymes & $\begin{array}{c}\text { Prestarter } \\
0-14 d\end{array}$ & $\begin{array}{c}\text { Starter } \\
15-28 d\end{array}$ & $\begin{array}{c}\text { Finisher } \\
29-42 d\end{array}$ & $\begin{array}{c}\text { Total } \\
0-42 d\end{array}$ \\
\hline $\mathrm{T}_{1}$ & 0 & $462.4^{\mathrm{bc}}$ & $1,448.8^{\mathrm{a}}$ & $2,322.2^{\mathrm{ab}}$ & $4,233.4^{\mathrm{ab}}$ \\
\hline $\mathrm{T}_{2}$ & $1 \mathrm{X} \mathrm{HC}$ & $455.0^{\mathrm{cd}}$ & $1,414.4^{\mathrm{a}}$ & $2,408.2^{\mathrm{a}}$ & $4,277.6^{\mathrm{a}}$ \\
\hline $\mathrm{T}_{3}$ & $2 \mathrm{X} \mathrm{HC}$ & $452.4^{\mathrm{d}}$ & $1,249.1^{\mathrm{c}}$ & $2,238.0^{\mathrm{b}}$ & $3,939.5^{\mathrm{d}}$ \\
\hline $\mathrm{T}_{4}$ & $1 \mathrm{X} \mathrm{LC}$ & $473.4^{\mathrm{a}}$ & $1,352.0^{\mathrm{b}}$ & $2,277.4^{\mathrm{b}}$ & $4,102.8^{\mathrm{bc}}$ \\
\hline $\mathrm{T}_{5}$ & $2 \mathrm{X}$ LC & $466.6^{\mathrm{ab}}$ & $1,256.0^{\mathrm{c}}$ & $2,267.0^{\mathrm{b}}$ & $3,989.6^{\text {cd }}$ \\
\hline \multicolumn{2}{|c|}{ SEM } & 1.65 & 14.74 & 19.07 & 27.64 \\
\hline \multicolumn{2}{|c|}{ P value } & 0.001 & 0.005 & 0.038 & 0.002 \\
\hline
\end{tabular}

Values bearing different superscripts within a column are significantly $(\mathrm{P}<0.05)$ different

Table 6: Effect of supplementation of non starch polysaccharide hydrolyzing enzymes to corn soybean meal diets on phase wise feed efficiency of broilers (1-6 wks of age)

\begin{tabular}{|c|c|c|c|c|c|}
\hline Treatments & Enzymes & $\begin{array}{c}\text { Prestarter } \\
0-14 d\end{array}$ & $\begin{array}{l}\text { Starter } \\
15-28 d\end{array}$ & $\begin{array}{l}\text { Finisher } \\
29-42 d\end{array}$ & $\begin{array}{l}\text { Total } \\
0-42 d\end{array}$ \\
\hline $\mathrm{T}_{1}$ & 0 & $1.43^{\mathrm{b}}$ & 1.70 & 1.95 & 1.78 \\
\hline $\mathrm{T}_{2}$ & $1 \mathrm{X} \mathrm{HC}$ & $1.36^{\mathrm{a}}$ & 1.60 & 1.97 & 1.75 \\
\hline $\mathrm{T}_{3}$ & $2 \mathrm{X} \mathrm{HC}$ & $1.44^{\mathrm{bc}}$ & 1.45 & 2.23 & 1.79 \\
\hline $\mathrm{T}_{4}$ & $1 \mathrm{X} \mathrm{LC}$ & $1.51^{\mathrm{c}}$ & 1.70 & 2.01 & 1.83 \\
\hline $\mathrm{T}_{5}$ & $2 \mathrm{X} \mathrm{LC}$ & $1.58^{\mathrm{d}}$ & 1.55 & 1.96 & 1.74 \\
\hline \multicolumn{2}{|c|}{ SEM } & 0.01 & 0.02 & 0.015 & 0.514 \\
\hline \multicolumn{2}{|c|}{$\mathrm{P}$ value } & 0.000 & 0.575 & 0.938 & 0.459 \\
\hline
\end{tabular}

Values bearing different superscripts within a column are significantly $(\mathrm{P}<0.05)$ different

\section{Discussions}

The present study revealed that body weight gain in the NSPHE fed diet @1X (HC) showed significantly $(\mathrm{P}<0.05)$ higher compared to other groups during overall period of the experiment. These findings are in agreement with Abbas et al. (1998) who reported that NSP enzyme supplementation to fibrous diet improved the growth rate of broilers. Zanella et al. (1999) investigated the effect of a commercial enzyme cocktail containing xylanase, protease and amylase on performance of broilers fed a corn-soybean meal based diet. Enzyme supplementation improved body weight gain. Hanumantha Rao et al. (2003) reported that the supplementation of enzyme cellulase, xylanase, amylase, protease and phytase individually to maize soybean based diets, significantly $(\mathrm{P}<0.05)$ improved body weight gains of broilers at 42 days. Edwin et al. (2004) observed significant increase in fifth week body weight gain $(\mathrm{P}<0.01)$ of the Japanese quail supplemented with NSP hydrolyzing enzymes. The diets supplemented with $1 \mathrm{X}, 2 \mathrm{X}$ (LC) and 2X (HC) did not shown any significant differences in body weight gains of broilers these findings are supported by Yuan et al. 2008, who reported that supplementation of multiple enzymes at $1 \mathrm{X}$ and $2 \mathrm{X}$ levels did not influence the BWG during overall period of 42 days. Narasimha Rao et al. (1998) indicated that the supplementation of NSP enzyme preparation to maize-soy bean based diets did not yield any significant improvement in the performance of broilers. In the present study broilers fed corn-soy based standard diet supplemented with $1 \mathrm{X}$ (HC) and $2 \mathrm{X}$ (LC) did show initial hike $(\mathrm{P}<0.05)$ in feed intake but failed to continue the same trend in the consecutive weeks. The control and diet supplemented with NSPHE @ 1X (HC) had significantly $(\mathrm{P}<0.05)$ higher feed intake during $2^{\text {nd }}$ to $4^{\text {th }}$ wk compared to birds fed on $2 \mathrm{X}$ (HC), $1 \mathrm{X}$ and $2 \mathrm{X}$ (LC) supplemented with NSPHE.The NSPHEs are more effective during pre-starter and starter phase compared with finisher phase, similar findings were reported by Berwal et al. (2008) who observed increased feed intake $(\mathrm{P}<0.05)$ in broilers fed diets with higher crude fibre levels supplemented with enzyme, Lazaro et al. (2003) who reported significant difference in feed intake when rye based diets were supplemented with $\beta$ glucanse 858 and xylanase 864 IU/g.Wang et.al (2005) reported improved $(\mathrm{P}<0.01)$ daily feed intake during 7 to 21 day phase. Nadeem et al. (2005) reported that supplementation of NSP degrading enzymes significantly $(\mathrm{P}<0.05)$ improved feed intake from 1-28 days. Ramesh and Chandrasekaran $\left(2011^{\mathrm{a}}\right)$ also reported significant increase in feed intake when standard diet was supplemented with enzymes. Shastak et.al. (2015) reviewed beneficial effects of $\beta$-mannanase in poultry. FCR was significantly better $(\mathrm{P}<0.05)$ in birds fed with NSPHE @ 1X (HC) when compared to rest of the treatment groups during pre-starter phase. During the starter phase birds receiving the NSPHE (a) 2X (HC) showed significantly better FCR compared to other treatment groups. The Finisher phase showed significant FCR in the control group followed by NSPHE supplemented@1X (HC) and 2X (LC) respectively. The diets with NSPHE@2X (HC) and 1X (LC) showed poor FCR during the finisher phase. These findings are in agreement with Swift et al. (1996), who reported that enzyme treatment significantly improved feed conversion in broilers over a 35-day feeding period. Zanella et al. (1999) investigated the effect of a commercial enzyme cocktail containing xylanase, protease and amylase on performance of broilers fed a corn-soybean meal based diet. Enzyme supplementation improved feed conversion ratio. Lazaro et al. (2003) found improved feed efficiency with NSP enzyme supplementation. Saleh et al. (2005) reported that feed conversion ratio was significantly improved in the NSP enzyme supplemented diets. Meng and Slominski (2005) recorded improved FCR with enzyme. Wang et.al (2005) found improved FCR $(\mathrm{P}<0.01)$ during 7 to 21 . However the supplementation of enzymes at $2 \mathrm{X}$ (HC), $1 \mathrm{X}$ and $2 \mathrm{X}$ (LC) levels had shown no significant effect with FCR these findings are in agreement with Narasimha Rao et al., (1998) who reported no significant effect of NSP enzyme supplementation in broilers. Hanumantha Rao et al. (2003) observed that the enzyme preparation inclusion to broiler diets did not improve significantly feed efficiency. Gao et al. (2007) and Berwal et al. (2008) reported no significant differences with feed efficiency. Rambabu (2009) reported no effect on feed intake and FCR of broilers fed either high fiber or low fiber diets supplemented with NSP enzymes. Cowieson et al. (2010) reported no significant improvement in FCR with NSP enzyme supplementation.

\section{Conclusion}

From this study it can be concluded that the NSPHE combinations@1X (HC) viz. (xylanase, ß-D-glucanase, cellulase, mannanase and pectinase@2400, 4800, 1800, 4800 , and $2400 \mathrm{IU} / \mathrm{kg}$ respectively have influenced the

\section{Volume 4 Issue 12, December 2015}




\section{International Journal of Science and Research (IJSR) \\ ISSN (Online): 2319-7064}

Index Copernicus Value (2013): 6.14 | Impact Factor (2014): 5.611

BWG, FI, FCR in broilers. The supplementation of NSPHE at $1 \mathrm{X}, 2 \mathrm{X}(\mathrm{LC})$ and $2 \mathrm{X}(\mathrm{HC})$ has not influenced the $\mathrm{BWG}$, FI, FCR in broilers.

Part of PhD thesis submitted to Sri Venkateswara Veterinary University, Tirupati - 517502, Andhra Pradesh, India

\section{References}

[1] Abbas W, Khan S H and Sarwar M 1998. Sunflower oil meal as a substitute for soybean meal in broiler rations with or without multi enzyme (kemzyme). Pakistan Veterinary Journal 18(3) : 124-129.

[2] Berwal R S, Lohan O P and Shiag Zile S 2008 Effect of dietary crude fibre levels and exzyme supplementation on performance and carcass characteristics of broiler chicks Indian Journal of Poultry Science 43:(2)175-178

[3] Choct M 2011 Feed Polysaccharides: Nutritional Roles and Effect of Enzymes presentation given at the IV CLANA CBNA/AMENA, Sao Pedro, SP, Brazil in November 2010 Engormix.com.

[4] Choct M 2006 Enzymes for the feed industry: past, present and future World's Poultry Science 81: 18421849.

[5] Cowieson A J, Bedford M R and Ravindran. V 2010 Interactions between xylanase and glucanase in maizesoy-based diets for broilers. British Poultry Science 51 (2) $246-257$.

[6] Duncans 1955 Multiple range and multiple F- tests. Biometrics 11: 1-42

[7] Edwin S C, Viswanathan K, Mohan B and Purushothaman M R 2004 Effect of supplementation of NSP hydrolyzing enzymes on growth performance of Japanese quails. Indian Journal of Poultry Science 39 (3):241-245.

[8] Hanumantha Rao M, Ravinder Reddy V and Ramasubba Reddy V 2003 Effect of commercial enzymes on the performance of broiler. Indian Journal of Poultry Science 38 (3), 291-293.

[9] Hong D, Burrows H and Adeola O 2002 Addition of enzymes to starter and grower diets for ducks. Poultry Science 81:1842-1849

[10] Lazaro R, Gracia M, Edel P and Mateas G G 2003 Influence of enzymes on performance and digestive parameters of broilers fed rye - based diets. Poultry Science 82: 132-40.

[11] Malathi V and Devegowda G 2001 In vitro evaluation of non starch polyaccharide digestibility of feed ingredients by enzymes. Poultry Science 80(3): 302305.

[12] Meng X and Slominski B A 2005 Nutritive values of corn, soybean meal, canola meal, and peas for broiler chickens as affected by a multicarbohydrase preparation of cell wall degrading enzymes. Poultry Science 84: 1242-1251.

[13] Nadeem M A, Anjum M I Khan A G and Azim A 2005 Effect of dietary supplementation of non-starch polysaccharide degrading enzymes on growth performance of broiler chicks. Pakistan Veterinary Journal 25 (4): 2005

[14] Narsimha Rao P V, Ramasubba Reddy V and Eshwaraiah, Shyamsunder 1998 Effect of enzymes in feed on broiler performance. M V Sc. Thesis submitted to ANGRAU Rajendranagar, Hyderabad.

[15] Rambabu 2009 Effect of exogenous enzymes in high fiber diets and their impact on broiler performance. MVSc thesis submitted to Sri Venkateshwara Veterinary University Tirupati

[16]Ramesh $\mathrm{J}$ and Chandrasekaran 2011 ${ }^{\mathrm{a}}$ effect of exogenous enzyme supplementation on performance of cockerels, Tamil Nadu Journal of Veterinary and Animal Sciences 7(1): 29-34.

[17] Saleh F, M Yamamoto, M Tahir, A Ohtsuka and K Hayash 2005 A new natural feed additive for broiler chickens. Poult. Sci. Asso. Annual Meeting. Edmonton, Canada, pp: 36-54.

[18] Saunders R M 1986 Rice bran: composition and potential food uses. Food Reviews Science Journal 62: 77-86.

[19] Shastak,Y, Ader,P Feuerstein, D Ruehle,R and Matuschek,M. $2015 \beta$-mannanas and mannanase in poultry Worlds Poultry Science Journal 71 :161-173

[20] Swift M L, Van Keyserlingk M A G, Leslie A, and Teltge D 1996 The effect of Allzyme Vegpro supplementation and expander processing on the nutrient digestibility and growth of broilers 12th Annual Symposium on Biotechnology in the Feed Industry Lexington, Kentucky Supplement1, enclosure code UL 21

[21] Wang Z R, Oiao S Y, Lu W O and Li D F 2005 Effects of enzyme supplementation on performance, nutrient digestibility, gastrointestinal morphology and volatile fatty acid profiles in the hindgut of broilers fed wheatbased diets. Poultry Science 84: 875-881.

[22] Yuan J, Yao J and Yang F 2008 Effects of supplementing different levels of a commercial enzyme complex on performance, nutrient availability, enzyme activity and gut morphology of Broilers. Asian Australian Journal of Animal Science 21(5):692-700.

[23]Zanella I, Sakomura N K, Silversides F G, Fiqueirdo A and Oack M 1999 Effect of enzyme supplementation of broiler diets based on corn and soybeans. Poultry Science78:561- 568. 